\title{
Contesting double displacement: internally displaced campesinos and the social production of urban territory in Medellín, Colombia
}

\author{
Claudia Maria López \\ Department of Sociology, California State University, Long Beach, California, USA \\ Correspondence: Claudia Maria López (claudia.lopez2@csulb.edu)
}

Received: 30 April 2018 - Revised: 12 June 2019 - Accepted: 13 June 2019 - Published: 18 July 2019

\begin{abstract}
This article offers an empirical account of the emotionally charged processes involved in the social production of territory. I draw from ethnographic interviews with displaced leaders of socio-territorial movements in Medellín, Colombia, who are resisting what I call double displacement. First, they were displaced from the Colombian countryside due to conflict and now, decades later, they are again being displaced, this time from their informal settlements due to urban development. Founders of settlements are now leaders of social movements, who reside on the periphery of the city and make claims to their neighborhoods using the slogan that they have a "right to the territory". I examine this case of double displacement to demonstrate the emotional and political aspects of re-territorialization by non-state actors at the urban scale. I argue that by applying a socioterritorial approach to examining the impact of double displacement, we recognize non-state territorialization as a realization and expansion of social power.
\end{abstract}

\section{Introduction}

In June 2014, I sit in a workshop of the escuela interbarrial popular (grassroots inter-neighborhood school) in a community center perched on the eastern mountain range above the city of Medellín. I listen to a female leader from the displaced community talking to a group of community leaders and activists from different barrios across Medellín about the right for them to stay in their neighborhoods and resist eviction caused by the planned implementation of urban development projects:

We, as campesinos, did not chose to be here. Our lives were in the countryside, where we worked with our hands, with the land and didn't have to beg the state to feed us. Now, after we have worked so hard for years to build this barrio, our homes, our community garden, they want to displace us again. They think we are stupid, but we are not. We have a right to our territories, and we must stand together as displaced campesinos and citizens.
The room, full of 50 or more people, many survivors of the conflict, rise to their feet, shouting and applauding in agreement.

With over 7 million people displaced since 1985, at the end of 2018 Colombia currently has the largest number of internally displaced people in the world (UNHCR, 2019). The primary cause of displacement is the more than 50year civil conflict between left-wing guerrillas, right-wing paramilitaries, and the Colombian military, who are all vying for territorial control (Bejarano and Pizarro, 2005; Avilés, 2001). The majority of the battles were waged in the countryside, which put small-scale farmers, or campesinos, directly in the path of the conflict and, as a result, they were direct and indirect targets of displacement. At total of 90 percent of displaced peasants resettle in the city (Albuja and Ceballos, 2010), highlighting urban areas in Colombia as key sites for state intervention through local programs of resettlement and transitional justice. Medellín - the second largest city in the country - has been a key receptor site because many zones of conflict are located in or near the department of Antioquia, where this city is the capital. As the displaced seek non-state sponsored forms of resettlement and integration, due to a lack 
of durable solutions to housing, displaced people have historically taken advantage of the peri-urban areas in the mountain ranges above the city of Medellín to auto-construct their neighborhoods. Drawing on memories of the rural past, identity and experiences as displaced campesinos, and collective imaginarios (imaginaries) (Echeverría and Rincón, 2000) as shown in the anecdote above - displaced leaders claim their right to the territory of their neighborhoods as displaced citizens. In contrast to cases such as Afro-Colombians and indigenous groups who have legal or ethnic claims to the land, displaced leaders resist repeat cycles of what I call "double displacement", by formulating political strategies rooted in the emotional language of belonging and victimization, as a way to anchor their rights and identities to the urban peripheries. I argue that displaced campesinos contest double displacement based on an emotionally charged process that forms their everyday acts of re-territorialization, which challenges state-centric conceptions of territory and territorialization. While scholars have offered thorough accounts on the theorization of the social production of territory (Schwarz and Streule, 2016; Haesbaert, 2013; Zibechi, 2012; Porto-Gonçalves, 2010; Echeverría and Rincón, 2000), this article offers an empirical account that demonstrates how dispossessed subjects understand and practice their right to (re)produce alternative territories at the urban scale.

This article contributes to current theoretical conversations on the social production of territory in two primary ways: first, I build on the de-territorialization and reterritorialization literature by spotlighting forced migration and urbanization as both expressions and consequences of contemporary dynamics of globalization, thus highlighting the strategies employed by de-territorialized people to reterritorialize at the urban scale. Second, by focusing on how displaced subjects (re)produce urban territory through socioterritorial movements, the case shows the emotional dimensions of social space as integral to the political claims and practices of displaced community leaders. Drawing from ethnographic interviews and participant observation with internally displaced peasant leaders of socio-territorial movements in Medellín, Colombia, this study demonstrates how internally displaced people experience and respond to cycles of de-territorialization and re-territorialization, revealing the tensions between space and power (Zibechi, 2012; Echeverría and Rincón, 2000). My research findings show that despite decades in the city, peasants continue to be socioeconomically and politically excluded from full participation in urban life. A lack of durable solutions - like stable housing - has resulted in protracted displacement and influences how and to what degree displaced communities and individuals integrate into the city. Now, for some, almost 2 decades after founding such neighborhoods, community leaders are demanding comprehensive betterment of their neighborhoods and defending their homes from demolition and eviction by urban development projects.
Campesino translates to a small-scale farmer, but the term has a much broader social meaning. Rather, as used in Colombia and other regions of Latin America, campesino refers to a social identity category of someone whose customs, beliefs, lifestyle and social, economic, political, and cultural practices are linked to rural land and economy. Despite years of living in the city, I found that displaced people living in the peripheries continue to identify strongly as campesinos and "displaced." Life in informal settlements of the displaced reproduces identities rooted in rural memories and practices, showing how space and emotions are coconstitutive processes that shape each other. The urban peripheries of Medellín are rural in nature, as the landscape transitions from the city center upwards (into the mountains) and over into the countryside. Here, while at the edge of the city, campesinos utilize their skills and knowledge to rebuild the material base of their territories at the urban scale. But displaced leaders also draw from rural identities and practices as strategies to construct "alter-territorialities" (Courtheyn, 2017) not solely based on state governance or capitalist accumulation. Instead, such strategies of collective re-territorialization (Brun, 2001) are shaped by multiple territorial understandings and practices of rurality and the emotionally embedded experience of displacement, trauma, and exclusion, which influences their present political claims to urban territory. Challenging state-centric approaches to territory is literature on non-state territorial production in Colombia (Courtheyn, 2017; Agnew and Oslender, 2013; Escobar, 2008; Echeverría and Rincón, 2000). Looking beyond territory as a set of places, this article draws attention to nonethnic-based territorial movements at the urban scale, drawing on territory as a "moving set of spatial practices, places and values that produces - and is produced by - particular political subjects" (Courtheyn, 2017:4). I use Bernardo Mançano Fernandes' definition of socioterritorial movements to frame the territorial movements of the displaced (Halvorsen et al., 2019). Halvorsen et al. (2019) argue that socio-territorial movements are unique from other social or socio-spatial movements. Fernandes states that "socioterritorial movements construct political spaces in order to reach their objectives, they spatialize and promote another type of territory, such that the large majority of socioterritorial movements are formed through processes of territorialization and deterritorialization" (Fernandes, 2005:24; Halvorsen et al., 2019:4). As Porto-Gonçalves (2010) also argues, space is integral to territorial movements, representing ongoing multidimensional and relational processes that seek the "transformation of sociospatial relations via the appropriation of space" (Halvorsen et al., 2019:4).

To better understand how displaced campesinos understand and practice the "right to the territory", the article asks two primary questions: first, how do de-territorialized subjects (re)produce urban territory? Second, what are the emotional aspects of the social production of territory? Reflecting on relational aspects of territory, I demonstrate how displaced 
peasants enact three interconnected "aspects of power relations in the production of territory" (Schwarz and Streule, 2016:1005). Namely, how these aspects have a material dimension, are infused with emotional meanings, and are politically strategic (Echeverría and Rincón, 2000:32). I utilize a socio-territorial approach developed by Latin American scholars (Santos, 2000; Echeverría and Rincón, 2000; Zibechi, 2012) to understand the material and relational processes involved in the production of alter-territorialities (Courtheyn, 2017; Agnew and Oslander, 2013) by different, and often conflicting, actors, practices, and meanings (Schwarz and Streule, 2016). In addition, this territorial approach is a method for identifying the power relations involved in the production of territory (Schwarz and Streule, 2016; Echeverría and Rincón, 2000). This perspective allows for a closer examination of re-territorialization, or how nonstate actors (re)produce territories, demonstrating the ways in which displaced people impact and shape urbanization as a political strategy. This sentiment is at the core of displaced leaders' claims to the right to the territory.

Double displacement represents the cyclical dynamics and outcomes of globalization that result in multiple displacements at different scales. The concept emphasizes the macrolevel and microlevel effects of 21 st century modes of global capitalist accumulation, namely forced migration and urbanization. At the macrolevel, double displacement is the current expression of globalization's impact on social space and humans. Understanding the link between migration and capitalist urbanization is important because the two processes feed each other and represent co-constitutive phenomena that result in serial displacements. At the microlevel, double displacement reveals other sites where displacements happen. Plainly, physical displacement is one event in a longer cycle of de-territorialization and re-territorialization (Echeverría and Rincón, 2000:17) that consists of people forcefully interacting with and moving through multiple spaces over time. However, displaced people also find ways to re-territorialize. Empirically, the socio-spatial analysis of territory at the urban scale highlights the material dimensions of global and local processes, like conflict and development, that shape the everyday urban territory and explain how and to what degree migrants will integrate. Theoretically, a closer investigation of double displacement and socio-territorial production in the city draws attention to territory as a social construct and the everyday practices where power is employed by local actors to resist further cycles of expulsion.

\section{De-territorialization}

Contemporary debates on globalization discuss new expressions of spatial order and authority that challenge statecentric conceptions of territory. Conventional approaches to territory conceive it from the perspective of a "terri- torial trap" (Agnew and Oslender, 2013; Brenner, 1999), where states are perceived as "the self-enclosed geographical containers of socioeconomic and politico-cultural relations" (Brenner, 1999:40), a material place related to issues of sovereignty and political rule (dell'Agnese, 2013; Painter, 2010). However, modern forms of capital accumulation erode geographical barriers via the expansion of transnational corporations and extractive economies; increase in speed of communications, transportation, and finance technologies; and the creation of new labor markets, all of which reconfigure territory and territorialization, "the act of creating territory by taking control of that space" (Courtheyn, 2017:6). The dynamics of de-territorialization and reterritorialization in Colombia have had devastating consequences on the lives of rural people living in the countryside. Deterritorialization in Colombia is expressed through the ambition of the country to insert itself into the global economy. This is accomplished by opening up the country to multinational companies based on extractive industries that mine for Colombia's vast natural resources, such as gold, oil, and even water. These industries drive the reconfiguration of geographic and social space by the exploitation of land and rivers for the benefit of development projects like hydroelectric dams and the expansion of interconnected roadways to move such commodities within and out of Colombia, decentering the role of the state. In addition, the battle between state and non-state armed actors over the control of land and power has resulted in the massive displacement of campesinos in Colombia and, I argue, demonstrates that conflict and development go hand in hand. I conceptualize the displacement of campesinos from the countryside, or place or origin, as the first wave of double displacement.

\section{Re-territorialization}

The drive towards "space-time compression" (Harvey, 1990), however, does not eliminate the necessity of place for the reproduction of capital under 21st century globalization. According to Brenner (1999), place remains necessary because fixed, place-based and specific infrastructure enables the continual cycle of capital accumulation. Re-territorialization then is another movement of globalization to re-root state territorial control at a subnational scale for the reproduction of capital. In this view, globalization is a "dialectical interplay" (Brenner, 1999) between de-territorialization and re-territorialization on which global capitalism is dependent for the circulation of capital, goods, and people. Re-territorialization intensifies state authority and social order at other scales, like the urban, thus remaking the geopolitical meanings and spatial organizations of territory and social power. According to Brenner and Schmid's theory of planetary urbanization, de-territorialization and reterritorialization create new scales of "interconnected urban nodes"; blurred and remade urban territorialities; destruction of the "hinterlands"; and the transformation of wilderness 
spaces (Brenner and Schmid, 2011). Re-territorialization at the urban scale is the rescaling of territoriality, "the use and control of territory for political, social, and economic ends" (Agnew and Oslender, 2013:123), whereby new forms of territorial organizations take advantage of the unique elements of the city to enable "expanded, accelerated movement" (Brenner, 1999:43). In the global south, cites then have become national projects of global economic insertion at the subnational scale.

Medellín is a good example of this type of national project. Once the homicide capital of the world, over the last decade entities like ProAntioquia, a private foundation composed of groups from the corporate sector, have worked closely with government in Antioquia to rebrand Medellín. Rebranding the city was key to address the development needs of Colombia. The city is a site of economic growth, yet, influenced by migration flows, globalization, and human mobility, challenge borders and belonging, urging us to look at the subnational as a national project (Greenberg, 2008; Brenner and Theodore, 2002). Medellín, as a new global city, attracts foreign investment as a major mode of development via urban greening and transportation projects as a strategy of global competition. Therefore, rebranding the crisis city of Medellín into a modern urban "miracle" is a process of boosting investment for economic growth, not just for the region but for the country (Greenberg, 2008; Brenner and Theodore, 2002). Resettlement in cities offers the hope of resources and opportunities for migrants to rebuild their lives. However, the rescaling of state territoriality at the urban scale means that strategies and representation of state governance affect vulnerable populations unevenly, targeting these communities by way of hyper-policing and surveillance; threats and violence from local gangs and paramilitary groups; lack of social services, like food, healthcare, and education; exclusion from the formal labor sector; high rental or real estate costs; and even green gentrification (Anguelovski et al., 2018). I understand these factors as consequences of state-led re-territorialization and elements that can lead to the second wave of double displacement at the urban scale.

However, since globalization represents ongoing, historically driven, cyclical movements that unfold simultaneously at different scales (Brenner, 1999), re-territorialization can also reveal the incompleteness of the state in its ability to truly exert full control over its territory (Agnew and Oslender, 2013). While re-territorialization also can result in the further dispossession of already marginalized populations, this moment offers an opportunity for non-state actors to take advantage of urban informality to reformulate their own understandings and practices of territory and territorial production, which can challenge state authority and power (Darling, 2017). Such gaps serve as moments of possibility for displaced people to insert themselves in processes of alterurbanization and produce spaces of belonging.

In their research on Afro-Colombian and indigenous socio-territorial movements in Colombia, Agnew and Oslen- der (2013) discuss the concept of overlapping territorialities to "describe alternative, and overlapping, forms of territory and territorial production beyond and outside the state" (Agnew and Oslender, 2013:135). These territorialities are considered other sources of territorial authority that also intersect with state territorialities. For example, how campesinos understand their relationship to and ownership of the land may overlap or even clash with how the state conceives of territory and territorial production. In these cases, these actors are in a contestation of space, but by using the concept of overlapping territorialities, we have a framework to examine how nonstate actors understand and practice re-territorialization processes "that imply the drawing of boundaries within nationstate territory" (Agnew and Oslender, 2013:121). The concept of overlapping territorialities brings into focus the multiple meanings, practices, and actors involved in territorial production and the instability of re-territorialization for state sovereignty. Other examples of territorial production in Colombia have also focused on the alternative production of territory by non-state actors. Courtheyn (2017), for instance, uses the case of the San José Apartado peace community in Urabá, Colombia, to discuss the relational aspect of what he calls alter-territorialities by tracing the spatial practices of the Peace community. From a socio-territorial approach, this case of double displacement in Colombia shows how globalization has reshaped the geopolitical landscape at the national and subnational scales, displaced campesinos practice, and (re)produced alter-territorialities in the face of serial displacements.

\section{Contesting double displacement and socio-territorial production of the displaced}

The larger project from which this article derives is based on ethnographic interviews $(n=118)$ and surveys $(n=112)$ with internally displaced people, government administrators, and nongovernmental organizations (NGOs) in Medellín, conducted between June 2011 and July 2016. For this article, I base my analysis on a subsample of 12 in-depth interviews with displaced community leaders -8 women and 4 men - during 2014. I highlight these 12 respondents because they are founders of the informal settlements where they live and prominent leaders in socio-territorial movements in their neighborhoods and across the city. Names of people and places in the study have been anonymized to protect the confidentiality of respondents.

In the following sections, I discuss the empirical findings drawn from interviews with displaced leaders to answer the leading questions of the article: how do de-territorialized subjects (re)produce urban territory, and what are the emotional aspects of social re-territorialization by non-state actors? Using the case of internal and forced migration is important because it focuses the role of the state as both sender and receiver, offering insight into the question of citizen- 
ship and territoriality. In this case, since the Colombian state supports urban structures, actors, and polices that result in double displacement, how displaced citizens re-territorialize contributes to conversations about the social production of territory by demonstrating the possibility of collective power by dispossessed people.

\subsection{Medellín's urban political geography}

Medellín's geography and history distinctly shape its reception of rural, displaced people. It is the second largest city in the country and located in the Valle de Aburrá, a valley surrounded by jutting mountain ranges to the east and west. Capital of the department of Antioquia in northwestern Colombia, Medellín is a primary route for the drug trade because the department extends from the mountainous Andean region - where coca is produced - to the Caribbean Sea where it is transported to buyer countries, like the United States. Since the early 2000s, Medellín has made a dramatic transformation from homicide capital to the site of the "Medellín Miracle" (Hylton, 2007). For example, Medellín was named Most Innovative City in the World in 2013 (Moreno, 2013), hosted the World Urban Forum in 2014 (World Urban Forum, 2019), and, in 2016, the city won the Lee Kuan Yew World City Prize for "outstanding achievements" towards sustainable living (Urban Redevelopment Authority, 2017). However, these accolades mask the dire reality of more than 400000 displaced people struggling to rebuild their lives on the margins of Medellín (Alcaldía de Medellín, 2015).

Medellín's landscape is split into different worlds: most dramatically between the urban city center and the peri-urban barrios that cling to the vertical mountain ridges that rise above the city, with some being more than $2000 \mathrm{~m}$ above the city center. This division is not solely geographic. Since the era of La Violencia, a civil war between 1948 and 1966, displaced campesinos have resettled on the peripheries of Medellín (Roldán, 2002), a phenomenon that has facilitated the informal development of the city. During 2014, the displaced communities of Medellín were debating with the mayor's office and city council over the absence of proposals from residents in the peripheral areas in the new Plan de Ordenamiento Territorial (POT) or Territorial Organization Plan. The POT is a renewing municipality-wide plan that outlines and budgets the urban development projects in the city for the next 15 years (POT, 2014). The debates were centered on the concern that most of the proposals sought to eliminate neighborhoods in the peripheries by relocating residents to the other side of the city, rather than support comprehensive betterment of infrastructure, for example, paved and maintained roads and access to services like drinking water and electricity. Some POT projects include Parques del Río, the building of parks along the length of the Medellín River, which runs through the middle of the city; new extensions of the "metro cable" system; a monorail; and the Cinturón
Verde and Jardín Circumvalar, a metropolitan green belt that runs across the eastern mountain range above the city (Personería de Medellín, 2015). The implementation of these urban development projects pushed into displaced communities and resulted in evictions and the demolition of the neighborhoods, causing a double displacement. The year 2014 was strategic for socio-territorial movements to mobilize at multiple scales, especially because the World Urban Forum - held in Medellín that year - gave organizers a national and international platform to show, as they claimed, the other face of Medellín. Over the year, in meetings, conferences, marches, and other movement spaces, displaced leaders challenged the city's projects by using the maxim of the right to the territory.

While displaced leaders said that they were not against development, the right to the territory meant a form of human development that included their imaginarios, or ideas for outcomes that addressed their specific needs for developing their full capacity (Echeverría and Rincón, 2000), in future plans for urbanization. Leaders asked first and foremost to stay in the neighborhoods and that the city focus on the betterment of their neighborhoods rather than a push for green gentrification that would evict them (Anguelovski et al., 2018). Eviction from the area would also strike a blow to their networks of work and subsistence. For example, in two comunas there were large community gardens where participating residents grew their own food and used the surplus to barter or sell for income. After a while, barrios became more urbanized, but the areas still represented a form of ongoing sets of relations and values based on community members' rural past and practices. While migrants find ways to integrate or facilitate modes of survival, what is unique about this form of placemaking by displaced campesinos is that their claim of the right to urban territory is used to make demands at different scales, such as claims to full Colombian citizenship. The other important factor to comprehend is that while the urban scale's informality offers an opportunity for the displaced to produce their own alter-territorialities, the city also creates a contentious space of struggle over urban territory and territorialization due to the competing and often violent overlapping territorialities.

\subsection{Struggles with overlapping territorialities}

The peripheries of Medellín have long been areas of exclusion and struggle for residents, causing tensions with other urban residents and actors over the right to territorial production. Roldán (1999) describes the historical perception of the peripheries, or comunas, and its residents by the city's elites: "Medellín's wealthier inhabitants invoked tropes of invasion and contamination to describe their sense of being besieged by a ring of slum dwellers who increasingly transgressed the ideological and physical space separating civilization from barbarism" (Roldán, 1999:173). Such perceptions of the peripheries and its residents has infiltrated urban politics and projects, often further to the detriment of 
these vulnerable populations. While the comunas have been essential for the resettlement of hundreds of thousands of displaced campesinos, offering a space of belonging, they are also stigmatized zones. Due to its informal nature, the absence of state authority is filled in by other non-state actors, like combos [criminal gangs] and paramilitaries, who recreate versions of state territoriality (Ballvé, 2012). Drawing invisible borders has resulted in another form of rescaling conflict territory since many urban paramilitaries were once armed actors in the countryside. The overlapping territorialities between non-state urban actors and the displaced have resulted in Medellín now being number one in the country for interurban displacement, that is, displacement from one barrio in the city to another barrio in the same city. Displacement occurs due to escalation of turf wars, threats, torture, killings, extortion, or simply over the demand to use a house for surveillance to take better aim at a rival. The understandings and practices of these conflict territorialities also influence the re-territorialization processes of the displaced and how they comprehend space and power.

At the citywide level, the alter-territorialities of the displaced leaders conflict with how state and private corporate actors, like the city planners, foreign investors, and the mayoral administration, conceive of territory and who can produce it. For city planners, the peripheral neighborhoods are invaded state property and need to be developed for the good of the city and, moreover, the economic growth of the country. The mayoral administration changes every 4 years, bringing different visions of what Medellín territory should look like. These visions drive projects and budgets that influence geopolitical space and social change, as well as redraw borders within the nation-state. For example, during 2014, Mayor Gaviria's term was based on urban development and innovation, resulting in a boom of several large-scale projects that threatened to displace vulnerable residents. But, by 2018 , with a new mayor, the visions for Medellín's future territorial production shifted from a focus on urbanism to that of security. No longer were calls from displaced leaders about the right to the territory based on responses to eviction threats, but now it was a right to live free from violence and conflict in their territories. However, not all from displaced communities are in line with socio-territorial movements that claim a right to the territory. Due to their experience with violence - in the countryside and city - many displaced campesinos fear what danger could befall them due to leaders high-profile organizing. In interviews with other nonleader displaced project participants, campesinos mentioned leaders "speaking too loud" or being guerilla sympathizers or scam artists. Even within neighborhood committees, I found that there were internal power conflicts, which often filtered into long-term divisions between community members. This was due to the fact that leaders were able to interact with different state officials at city, regional, and national scales, giving them the chance to benefit from special opportunities. For example, one leader said that she and her husband re- ceived free dental work because a group of US businessmen came to a town hall meeting with leaders and wanted to donate that service.

Such examples of the different overlapping territorialities in Medellín set the context in which displaced campesino leaders are (re)producing alter-territorialities. At the urban scale we can more clearly see the intersection of struggles over territory by different actors, structures, and meanings at multiple scales over time. However, as Zeiderman (2017) argues, popular social movements are "made up of daily struggles between urban dwellers and state agencies over the distribution of municipal benefits, services, and infrastructure, such as housing, water, transportation, or electricity" (Zeiderman, 2017:315), rather than radical change. While the state is trying to quell new informal development in the periphery by way of urbanization projects like the green belt, government city officials have worked with leaders little by little over time to implement an infrastructure in the peri-urban areas. Therefore, this case shows, as have others (Asher, 2009), that socio-territorial movements are not revolutionary but rather are shaped both by geopolitical politics and state strategies and language based on exclusion, risk, and victimization. Yet, still, these grassroots territorial movements and their alter-territorialities need to be taken seriously because the ways in which they understand and practice territorialities will shape the urban social space and affect the subnational project. As Agnew and Oslender (2013) contend, "acknowledging the presence of other territorial authorities within the space of the nation-state" (Agnew and Oslender, 2013:130) will help legitimate and encourage a more democratic process that can create new stability within the nation-state.

\subsection{Understanding and practicing alter-territorialities in Medellín}

I found that barrio-building [neighborhood] and territorybuilding are understood by the displaced as co-produced yet distinct processes. While building the barrio refers to the material production of place, that is, the development of the land, neighborhood, homes, etc., territory-building means the ongoing production of spatial and social relations. Juan, a 65year-old mestizo leader who resettled in Medellín 20 years ago, helped found a now established neighborhood. Juan gives me a tour of the neighborhood located in Comuna 8, walking me up and down the steep concrete steps that run up the vertical mountain range to meet neighbors. Juan tells me about how the barrio started:

Everything started when we began the process of petitioning our status as displaced. There was a group of us who met at the United Nations [seeking aid], and we began saying, why don't we begin a settlement, a neighborhood. Some people said, what, up there? No way! A leader came out and said, "I live there in that barrio and there is a very 
large terrain, come on! We are going to take over that land." Everyone said, yes! And that's when it started, with 10 families from different places that found each other through the process of going to the United Nations. As we ran into people [making rounds for aid] we told them, hey, come build your ranchito [shack] up there! And from there we started building, started building... and now we are a settlement with like, 1000 families, or more.

Juan's quote highlights two important elements of socioterritorial production: the material and social processes. Juan talks about the importance of social networks, of "finding each other" as a new community. It represents a moment of collective agency in the process of resettlement that does not rely on the state. However, the material construction of the barrio also serves as an important process of integration that developed into a collective territorialization with others who were also displaced from the countryside.

Marta is a 38-year-old Afro-Colombian woman who, when interviewed in 2014, was still living in the neighborhood she helped build 18 years ago. She had been displaced from northern Antioquia when paramilitaries attempted to kill her husband, who worked in the banana plantations of Uraba. When she arrived to Medellín, she was alone, having left her two children at the time with her mother. Marta spent the first months going back and forth to the state agencies, where she connected with Juan at an aid organization downtown. Juan convinced Marta to come up to the peripheries and help a group of displaced campesinos like herself build a neighborhood. Marta talks about building the neighborhood and the process of territory-building:

This is a community of the displaced... us being the first here we were able to help a lot because a person, when they are displaced, it is something really worrisome to know that you were in the countryside, like we were in Urrao, that you were in your country home, your farm, your animals, your beautiful home... for a person to arrive, huddled with four or five families, without knowing how you are going to live, what you are going to eat... so in this scenario it was something beautiful to be able to offer your home to arriving families while they resettled, to show them around, to give them a blanket.

Marta verbalizes that a sense of community built through the material founding of the neighborhood facilitated the production of the territory as a set of relations. Based on rural understandings and practices, these barrios are infused with memories of the countryside and the collective feelings of loss and trauma. These emotions create a sense of solidarity with others who also identify as displaced and as campesinos. The experience of helping incoming displaced people facilitated the development of leadership skills and a sense of creating a space of belonging for others in similar circumstances. This can be understood as a socio-territorial practice of co-building territory. These examples add to debates on non-state conceptions of territory and territorial production in Colombia, which have mostly focused on the lives and experiences of Afro-Colombian and indigenous groups and their struggle for land rights in the countryside (Courtheyn, 2017; Agnew and Oslender, 2013; Escobar, 2008; Grueso and Arroyo, 2005). Research by Escobar (2008), for example, examines the interrelated aspects of social, cultural, and biological life involved in territorial production by Afro-Colombian and indigenous activists of the Pacific region of the country. He calls for an examination of alternative strategies for understanding the production of "territories of life" through "place-based strategies that rely on the attachment to territory and culture and network that enable social movements to enact a politics of scale from below" (Escobar, 2008:32). In their research on Afro-Colombian women's territorial movements, Grueso and Arroyo (2005) examine Afro-Colombian communities that live on the Pacific coast to discuss the defense of the territory as a means of reproducing the territory as sets of relations. In this context, the authors argue that the territory is a deeply spatial and relational process: "The territory is seen as constructed by the community on the basis of the 'use space' (espacios de uso) of the ecosystems that sustain the life project of the community" (Grueso and Arroyo, 2005:102). Defending the territory is also a process of knowledge production for social reproduction and survival. Therefore, forced displacement not only entails the loss of homes and farms, but it also uproots relations and practices and feelings of belonging. In this vein, for displaced campesinos in Medellín, resisting double displacement is not solely based on the material building of their neighborhoods but also in their resistance to dominant narratives about property, land, and development, all of which drive their political formation and how they view themselves as displaced citizens. Through escuelas populares (or grassroots community schools), like the one described in the opening anecdote, displaced leaders develop strategies-based emotional language of belonging and victimization to reproduce life projects in the peripheral communities.

\subsection{The emotional aspects of urban re-territorialization}

In this section, I discuss how displaced leaders utilize collective memory, experiences, and imaginarios to make connections between their rights, identity, and neighborhood spaces. Emotions are a critical element for understanding the relational aspect of territorialization because emotions are an "intimate link between the social and the concrete physical world that is experienced" (Richter, 2015:141). Emotions are a key part of the relational aspect of territorial production because "emotions give deep meaning to these negotiations and highlight the importance of certain experiences over others. 
They also act as a sort of signal by marking moments, interactions, and incidents that are particularly relevant for the people who feel these emotions" (Richter, 2015:141). Emotions are spatiotemporal and shaped by past histories and collective memories; thus, how we feel about a particular place will influence our sense of belonging and the processes involved in how we imagine our possible futures.

Maria Elena is a 39-year-old mestiza woman who became a local celebrity in the activist community in Medellín for mobilizing her barrio to demand that the displaced sit at the table with urban activists and city developers. She has organized aggressively against the implementation of the POT, demanding that her community stay in the territory. Here, Maria Elena uses emotional language to discuss how the founders became more politicized, moving from being solely focused on settlement-building to demanding collective rights:

we started with a small group, a small group of people from our sector... and it went growing, growing, until we became a part of the comuna, and we said, hey, we need to think about residents who are victims. We are here not because we want to be. We are here because we had to, and due to that, we need to position ourselves as a group that have rights and we need to demand them as a group. We have rights but we have to defend them, and after we defend them we have to have them recognize them and guarantee them. From there we began organizing, not only with the neighborhood ... but with others on the local development committee to construct the development from our community, [asking ourselves] 'How do I imagine my neighborhood to be, how do I dream my comuna will be, how do I dream as a victim living in this city.'

From this quote, we can see how displaced leaders are asking members to use their imaginations to collectively dream the territory as a manifestation of their rights, both as victims and citizens. Imaginarios are spatial representations based on a material foundation, with a particular understanding of territoriality that is infused with sentiments and meanings that point towards new possibilities and hopeful futures (Schwarz and Streule, 2016; Echeverría and Rincón, 2000). Maria Elena's interview also highlights how having land is imperative to territorial production. Without land and its resources as the material base, it is impossible to weave the social fabric of the territory. The land then is understood in relation to the territory, which is inherently social. I argue that these emotions are important to understand in the context of social leaders' personal affection to soil and at the root of their territorial claims and practices. For campesinos, the land and territory represent sources of independence and survival. While campesinos ranged from largeplantation-owning farmers to sharecroppers, and even small rural merchant-supported households, interviewees all identified as campesinos and felt the loss of land and territory as a loss of productivity and self-sufficiency. The shift from a land-based economy to a money-based economy was the biggest barrier to urban integration.

In this last quote, Maria Elena demonstrates how displaced leaders reproduce the territory by defending the neighborhood from double displacement:
We, as victims, when we arrived to the [barrios] identified, eh, that this can be a way to return to the countryside, reintegrate ourselves to a new so- ciety, a community, which is what one loses when you have to leave the territory... and we defend this territory because we feel it like it is part of us. We feel that this territory, opened its doors to us when the city closed them to us... so while this is happening the community grabs [the displaced] and says you count and embrace them as part of us, the countryside, the land, the pure air (laugh- ing) unfortunately, the air isn't $100 \%$ pure, but we find a space to breathe. That has been something very beautiful because when you look up at the pe- ripheries you know that the residents are victims, and who do you see? Trees, mountains, and who is up there? Us.

In this context, we see how leaders make emotional connections between belonging, victimization, and the land to discuss how they understand and practice socio-territorial production. In this way, we see how and why leaders understand and practice territory production as a form of both making physical and social spaces of belonging. Therefore, their exclusion from formal urban life helps reproduce a community based on the identity of the displaced, an identity which drives the construction of the territory and, at the same time, the territory in turn functions to reconstitute this collective identity. In this sense, these neighborhoods represent the ongoing remaking of rural territorial meanings at the urban scale. From this example, we recognize how the contestation of double displacement offers a lens for understanding how non-state subjects understand and practice alter-territorialities as an emotionally charged process.

\section{Conclusion}

In 2016 Colombia signed the Peace Accord with the FARC. While this was a historically significant moment, even earning President Santos the Nobel Peace Prize, the deal is now in danger of failing and the rates of displacements continue, with 38490 people displaced between 1 January and $31 \mathrm{Au}-$ gust 2018 alone (CODHES, 2018). This is mainly due to the Colombian state's lack of accountability and a general disagreement among FARC soldiers about demobilization. The process of possible demobilization has also created tensions 
in the city as criminal gangs and paramilitaries tightened their grip on territorial control of Medellín. This has affected social leaders in the city like Maria Elena, who, due to her leadership work, had been displaced to the other side of the city by the local gangs by the end of 2018 . Her community work has now faltered and the committee of displaced leaders in her area was no longer organizing when I returned for follow-up fieldwork in December 2018-January 2019. The dynamics of globalization are continually reconfiguring the geopolitical and social space as new and more overlapping territorialities seek legitimacy and power at the urban scale.

This article offers an empirical example of how displaced actors experience and respond to cycles of deterritorialization and re-territorialization under contemporary globalization. I foreground the phenomenon of double displacement to highlight how global processes are localized at different scales and how different groups of actors understand and struggle over territory and power. This examination of double displacement highlights urban scales as key sites for rescaling state territoriality but also recontextualizes the urban in relational ways at different scales, for example, at global, urban, and rural scales. For instance, the case of socio-territorial movements of displaced people in Medellín shows how a group of peasants implement rural territorial practices and meanings for urban integration and, later, to resist development-induced displacement and make demands heard at the national scale.

I found that displaced leaders struggled against other overlapping territorialities as part of their ongoing development and defense of their alter-territorialities. Displaced campesinos understood territory as a set of relations and values based on rural meanings, knowledge, and practices based on collective construction of material and social processes. For example, barrio-building, the physical building of the neighborhoods, was foundational to these social processes since territorial production necessitates the material base of land. Over time, through solidarity and shared memories and experience of displacement, campesino leaders used emotional language of belonging and victimization to connect their rights and identities - as displaced and campesino - to the particular space. By using their imaginarios ("How do I imagine my city?") displaced leaders and community members infused emotional meaning into constructing the material and social production of the territory.

The socio-territorial approach is useful for understanding the lived experience of double displacement and offers an opportunity to examine how non-state actors re-territorialize, thus highlighting the everyday, emotionally embedded strategies employed by displaced subjects to enact power on their own behalf (Zibechi, 2012). I apply this approach to show how re-territorialization is a form of power and how space influences this process. By foregrounding urban reterritorialization, the study highlights how migrants make their own spaces of belonging, as part of their political claims. Understanding how and to what degree people feel a part of their own nation is important because national belonging is key for the stability of a nation-state and the strengthening of national democracy. This is particularly important for a country like Colombia which now seeks to find peace after more than 5 decades of internal conflict.

Data availability. No datasets were used in this article.

Competing interests. The author declares that there is no conflict of interest.

Acknowledgements. I would like to thank all participants of the 2017 AAG Contesting Territories in Latin America panel, and especially the organizers and special issue editors, Anke Schwarz and Monika Streule, for their guidance on early drafts. I also acknowledge Miriam Greenberg and Emily Mitchell-Eaton, as well as the two anonymous reviewers, for their helpful suggestions, and J. Francisco Romero for their continued support of the larger project. A special thank you goes to Jonathan Fox, who first encouraged a serious examination of el territorio.

Financial support. This research has been supported by the Chicano Latino Research Center's Andrew W. Mellon Foundation John E. Sawyer Seminar Graduate Student Fellowship on Noncitizenship (grant no. FOAPAL 58395-445184).

Review statement. This paper was edited by Myriam HoussayHolzschuch and reviewed by two anonymous referees.

\section{References}

Agnew, J. and Oslender, U.: Overlapping territorialities, sovereignty in dispute: empirical lessons from latin america, in: Space of Contestation: Spatialities and Social Movements, edited by: Nicholls, W., Miller, B., and Beaumont, J., Ashgate, Farnham, UK, 121-140, https://doi.org/10.1002/9781118786352.wbieg1106, 2013.

Alcaldía de Medellín: Desplazamiento forzado y desplazamiento forzado intraurbano: contexto y dinámica en Medellín durante el 2014, Unidad Municipal de Atención y Reparación a Víctimas, Medellín, Colombia, 35 pp., available at: https://www.medellin.gov.co/irj/go/km/docs/ pccdesign/SubportaldelCiudadano_2/PlandeDesarrollo_ 0_0_0_0/Informes/SharedContent/Documentos/2015/ 11DFI-Contextodinamica2014_Mayo2015.pdf (last access: 11 July 2019), 2015.

Albuja, S. and Ceballos, M.: Urban displacement and migration in Colombia, Forced Migr. Rev., 34, available at: https:// www.fmreview.org/urban-displacement/albuja-ceballos (last access: 11 July 2019), 2010.

Anguelovski, I. Irazábal-Zurita, C., and Connolly, J.: Grabbed urban landscapes: Socio-spatial tensions in green infrastruc- 
ture planning in Medellín, Int. J. Urban Regional, 43, 1-24, https://doi.org/10.1111/1468-2427.12725, 2018.

Asher, K.: Black and green: afro-colombians, development, and nature in the pacific lowlands, Duke University Press, Durham and London, 2009.

Avilés, W.: Institutions, military policy, and human rights in colombia, Lat. Am. Perspect., 28, 31-55, https://doi.org/10.1177/0094582X0102800103, 2001.

Ballvé, T.: Everyday state formation: territory, decentralization, and the narco landgrab in Colombia, Environ. Plann. D., 30, 603622, https://doi.org/10.1068/d4611, 2012.

Bejarano, A. M. and Pizarro, E.: From "restricted" to "besieged": The changing nature of the limits to democracy in colombia, in: The Third Wave of Democratization in Latin America: Advances and Setbacks, edited by: Hagopian, F. and Mainwaring, S. P., New York, Cambridge University Press, US, 235-260, 2005.

Brenner, N.: Beyond state-centrism? Space, territoriality, and geographical scale in globalization studies, Theor. Soc., 28, 39-78, https://doi.org/10.1023/A:1006996806674, 1999.

Brenner, N. and Schmid, C.: Planetary urbanization, in: The Globalizing Cities Reader, 2nd edition, edited by: Ren, X. and Keil, R., Routledge, Abingdon, United Kingdom, 479-482, https://doi.org/10.4324/9781315684871, 2017.

Brenner, N. and Theodore, N.: Cities and the geographies of "actually existing neoliberalism", Antipode, 34, 349-379, https://doi.org/10.1111/1467-8330.00246, 2002.

Brun, C.: Reterritorializing the relationship between people and place in refugee studies, Geogr. Ann. B., 83, 15-25, https://doi.org/10.1111/j.0435-3684.2001.00087.x, 2001.

CODHES (Consultoría para los Derechos Humanos y el Desplazamiento): Tablero: Desplazamiento forzado interno múltiple y masivo, 2018.

Courtheyn, C.: Territories of peace: alter-territorialities in colombia's san josé de apartadó peace community, J. Peasant. Stud., 45, 1-28, https://doi.org/10.1080/03066150.2017.1312353, 2017.

Darling, J.: Forced migration and the city: irregularity, informality, and the politics of presence, Prog. Hum. Geog., 41, 178-198, https://doi.org/10.1177/0309132516629004, 2017.

dell'Agnese, E.: The political challenge of relational territory, in: Spatial politics: essays for Doreen Massey, edited by: Featherstone, D. and Painter, J., Wiley-Blackwell, Chichester, West Sussex, 115-124, 2013.

Echeverría, M. and Rincón, A.: Ciudad de territorialidades. Polémica de Medellín, Medellín, Centro de Estudios del Hábitat Popular; Universidad Nacional de Colombia, 2000.

Escobar, A.: Territories of difference: place, movements, life, redes, Duke University Press, Durham and London, 2008.

Fernandes, B. M.: Movimentos socioterritoriais e movimentos socioespaciais: contribuição teórica para uma leitura geográfica dos movimentos, Sociais Revista Nera, 8, 14-34, 2005.

Greenberg, M.: Branding New York: How a city in crisis was sold to the world, Routledge, New York, US, 2008.

Grueso, L. and Arroyo, L. A.: Women and the defense of place in Colombian black movement struggles, in: Women and the Politics of Place, edited by: Harcourt, W. and Escobar, A., Kumarian Press, Bloomfield, US, 100-114, 2005.

Haesbaert, R.: A global sense of place and multi-territoriality: notes for dialogue from a "peripheral" point of view, edited by: Feath- erstone, D. and Painter, J., Wiley-Blackwell, Chichester, West Sussex, 146-157, 2013.

Halvorsen, S., Fernandes, B. M., and Torres, F. V.: Mobilizing territory: socioterritorial movements in comparative perspective, Ann. Am. Assoc. Geogr., 1-17, https://doi.org/10.1080/24694452.2018.1549973, 2019.

Harvey, D.: The condition of postmodernity, Blackwell, Oxford, UK, 1990.

Hylton, F.: Medellín's makeover, New Left Rev., 44, 71-89, 2007.

IDMC (Internal Displacement Monitoring Centre): Global report on internal displacement 2017, edited by: Lennard, J., Internal Displacement Monitoring Centre, Norwegian Refugee Council, 2018.

Moreno, C.: Medellin, colombia named "innovative city of the year", in WSJ and Citi global competition, The Huffington Post, available at: https://www.huffpost.com/entry/medellinnamed-innovative-city-of-the-year (last access: 11 July 2019), 2013.

Painter, J.: Rethinking territory, Antipode, 42, 1090-1118, https://doi.org/10.1111/j.1467-8330.2010.00795.x, 2010.

Personería de Medellín: Observatorio de reasentamientos y movimientos de población del municipio de medellín, Universidad de Naciónal de Colombia, Facultad de Arquitectura, Medellín, Colombia, 2015.

POT (Plan de Ordenamiento Territorial): de Medellín: Acuerdo 48 de 2014, Alcaldía de Medellín, 877 pp., 2014.

Porto-Gonçalves, C. W.: Territorialidades y lucha por el territorio en América Latina, Geografía de los movimientos sociales en América Latina, Caracas, IVIC, 2010.

Richter, M.: Can you feel the difference? Emotions as an analytical lens, Geogr. Helv., 70, 141-148, https://doi.org/10.5194/gh-70141-2015, 2015.

Roldán, M.: Cocaine and the miracle of modernity in medellín, in: Cocaine: Global Histories, edited by: Gootenburg, P., Routledge, London and New York, 165-182, 1999.

Roldán, M.: Blood and fire: La violencia in Antioquia, Colombia, 1946-1953, Duke University Press, Durham, US, 2002.

Saquet, M. A.: A perspective of counter-hegemonic analysis and territorial transformation, Geogr. Helv., 73, 347-355, https://doi.org/10.5194/gh-73-347-2018, 2018.

Schwarz, A. and Streule, M.: A transposition of territory: Decolonized perspectives in current urban research, Int. J. Urban Reg. Res., 40, 1000-1016, https://doi.org/10.1111/1468-2427.12439, 2016.

United Nations High Commissioner for Refugees (UNHCR): Global trends: forced displacement in 2018, The UN Refugee Agency, Geneva, Switzerland, available at: https://www.unhcr. org/globaltrends2018/, 76 pp., last access: 16 July 2019.

Urban Redevelopment Authority: 2016 Prize Laureate: Medellín, available at: https://www.leekuanyewworldcityprize.com.sg/ laureates/laureates/2016/medellin (last access: 11 July 2019), 2016.

World Urban Forum (WUF): 7th World Urban Forum Medellín Declaration, UN Habitat, available at: https://unhabitat. org/7th-world-urban-forum-medellin-declaration/, last access: 12 July 2019.

Zeiderman, A.: Endangered city: security and citizenship in bogota, in: The SAGE Handbook of the 21st Century City, edited by: 
Hall, S. and Burdett, R., Sage Publications, London, UK, 314331, https://doi.org/10.4135/9781526402059, 2017.
Zibechi, R.: Territories in resistance. A cartography of Latin American social movements, AK Press, Oakland, US, 2012. 